\title{
Microbial Studies of Biosurfactant Producing Bacteria from Crude Oil Contaminated
} Soil

\author{
*OGRU, KI; OLANNYE, PG \\ Department of Microbiology, University of Benin, Benin-city, Edo State, Nigeria \\ *Corresponding Author Email: ighoogru@gmail.com
}

\begin{abstract}
Soils contaminated with crude oil collected from three sites in Delta State were analyzed using serial dilution and pour plate methods. The physicochemical characteristics of the soil were determined using standard methods. The mean heterotrophic bacteria count and the mean hydrocarbon utilizing bacteria count were also determined. Blood haemolysis, foaming activity, oil spreading techniques and emulsification assay was used to screen the microorganisms for biosurfactant production. The biosurfactant producing bacteria were selected and their effect on metal removal and growth kinetics was also determined. The $\mathrm{pH}$ of the contaminated soil samples ranged 4.82 to 5.62. The mineral elements such as potassium $\left(\mathrm{k}^{+}\right)$and sodium $\left(\mathrm{Na}^{+}\right)$ranged from 0.20 to $0.80 \mathrm{Meq} / 100 \mathrm{~g}$ and 0.07 to $0.81 \mathrm{Meq} / 100 \mathrm{~g}$ respectively. The heavy metal content such as zinc $\left(\mathrm{Zn}^{2+}\right)$ and lead $\left(\mathrm{Pb}^{2+}\right)$ ranged from 10.13 to 19.24 $\mathrm{mg} / \mathrm{kg}$ and 19.24 to $49.63 \mathrm{mg} / \mathrm{kg}$ respectively. Organic carbon and THC ranged from 5.44 to $6.87 \%$ and 2720.00 to $3110.00 \mathrm{mg} / \mathrm{kg}$ respectively. The mean heterotrophic bacteria and hydrocarbon utilizing bacteria ranges from $1.4 \pm 0.4$ x $10^{6}$ to $1.6 \pm 0.7 \times 10^{6}$ and $1.0 \pm 0.2 \times 10^{6}$ to $1.2 \pm 0.4 \times 10^{6}$ respectively in the soil samples. Bacteria isolated and identified from the three sites include Corynebacterium spp., Bacillus subtilis., Pseudomonas aeruginosa, Micrococcus varians, Streptococcus spp., Klebsiella spp. and Enterobacter spp. with Bacillus subtilis and Pseudomonas aeruginosa having the highest prevalence and among these isolates only Corynebacterium spp., Bacillus subtilis., Pseudomonas aeruginosa and Micrococcus varians showed positive result for the production of biosurfactant. Bacillus subtilis had the highest metal removal capacity of $29.44 \%$ of $100 \mathrm{ppm}$ of lead. Corynebacterium spp. and Bacillus subtilis had an optimum growth at $\mathrm{pH} 8$ and 7 respectively while Pseudomonas aeruginosa and Micrococcus varians has an optimum growth at $\mathrm{pH}$
\end{abstract}

\section{DOI:https://dx.doi.org/10.4314/jasem.v25i9.27}

Copyright: Copyright (c) 2021 Ogru and Olannye. This is an open access article distributed under the Creative Commons Attribution License (CCL), which permits unrestricted use, distribution, and reproduction in any medium, provided the original work is properly cited.

Dates: Received: 09 May 2021; Revised: 12 August 2021; Accepted: 12 September 2021

Keywords: Biosurfactant, Hydrogen Ion, pH, Metal removal

Biosurfactant are surface active molecule that are mainly synthesized extracullarly and as part of cell membrane by certain microorganisms which are amphyphilic in nature, that is, having hydrophilic (water loving) and hydrophobic (exclude water) moleties which confers them with the capacity to exist between phases such as water/air or water/oil, thus helps to minimize the surface and interfacial tension of the surface and interface respectively (Banat 1995; Karanth et al., 1999). Biosurfactant microorganisms make use of organic compound as carbon and energy source for growth. When these carbon and energy sources are in insoluble form such as hydrocarbon, they either make the influx of hydrocarbon possible by producing biosurfactant or the nature of the cell wall is modified and this is done via production of nomionic or lipopolysaccharide surfactant in their cell wall (Guerra et al., 1984; Hauser and Karnovesky, 1954; Guerra et al., 1986). The fate of petroleum hydrocarbon in the soil depend on the biodiversity of biosurfactant as well as hydrocarbon utilizing microorganisms in the contaminated soil in that numerous indigenous microorganisms such as bacteria, fungi, actinomycetes are capable of using hydrocarbon as source of carbon and energy for growth. Also, the major factor influencing the biodegradation of crude oil pollutant in the environment is their non-availability to microorganisms. Thus, ways to activate these potentials must be considered in that most degradation potentials are widely distrusted among microorganisms and also indigenous microbes are usually present in a very small amount. Hydrocarbon varies in their susceptibility to microbial attack and their biodegradability in soil is determined by various factors such as nutrient, oxygen, $\mathrm{pH}$, composition, concentration and bioavailability of the contaminant as well as the soils physicochemical characteristics. Synthetic surfactant cannot be used in the cleanup of soils polluted with crude oil in that it has very negative and detrimental effect on humans as well as the environment. Bioremediation requires large amount of biosurfactant microorganism but there are problem of low yield and high production cost, thus reducing their 
industrial application. Microbial degradation of soil polluted with crude oil is the major natural means of remediating crude oil contaminated environment (Akpoveta et al., 2011) and more biosurfactant producing microorganisms should be identified, studied and employed in remediation process as diverse groups of bacteria and fungi have been isolated from soils polluted with crude oil and shown to produce biosurfactant and degrade hydrocarbon in the laboratory.

\section{MATERIALS AND METHODS}

Sample Collection: Soil sample was collected from crude oil contaminated soil from three sites, Batan Community, Odidi community and Kantu community, all in Warri-Southwest Local Government Area Delta State. This was done with the help of a clean hand trowel at about $5 \mathrm{~cm}$ depth, which is the top soil where the concentration of the contaminant is expected to be high. The samples were kept in a clean plastic polyethylene bag and were transported to the laboratory for analysis (Karthik et al., 2010).

Physicochemical analysis of crude oil contaminated soil: The $\mathrm{pH}$ reading was obtained with the aid of a Hanna microprocessor $\mathrm{pH}$ multimeter (Ekaise and Nkwelle, 2011) Determination of $\mathrm{Na} \mathrm{K} \mathrm{Mg} \mathrm{Ca} \mathrm{was}$ determined using a flame photometer according to methods of Onyeonwu, (2000). Minerals (heavy) metals analyses for determination of Zinc (Zn), Iron $(\mathrm{Fe})$, Mercury $(\mathrm{Hg})$, Lead $(\mathrm{Pb})$ and Copper $(\mathrm{Cu})$, were done by aspirating the solution for (analysed) each metal analysis into the Atomic Absorption Spectrometer (ASS) PG 550 model (Adelekan and Abegunde, 2011). Determination of Nitrate, Sulphate and total organic carbon was done using methods described by Onyeonwu, (2000). THC was extracted using $\mathrm{n}$ - hexane (Akpoveta et al., 2011).

Isolation and Enumeration of Microorganism: Ten (10) gram of the samples was weighed into sterile beaker and $90 \mathrm{ml}$ of sterile distilled water was added. This was thoroughly mixed and serial diluted up to $10^{-}$ ${ }^{6}$ using 10 fold dilutions. One (1) $\mathrm{ml}$ of the dilution was plated in nutrient agar for bacteria isolation and in potato dextrose agar for fungi isolation, both in duplicates. The nutrient agar plates were incubated at $35^{\circ} \mathrm{C}$ for 48 hours while the potato dextrose was incubated at room temperature. After incubation, the number of discrete colony on the plate was counted in terms of $\mathrm{Cfu} / \mathrm{g}$ using $0.1 \mathrm{ml}$ inoculums size.

Enumeration and Isolation of Hydrocarbon Utilizing Bacteria:Bacteria with hydrocarbon degrading ability were isolated from the contaminated soil samples using mineral salt agar that is added with $15 \mathrm{~g}$ of agar and about $1 \%$ crude oil as carbon source (Amund et al., 1987), with a final $\mathrm{pH}$ of 7.0. One (1) $\mathrm{ml}$ of $10 \mathrm{mg} / \mathrm{l}$ Nystsatin was applied to the plate to prevent Fungi growth. The culture plates were then incubated at $35^{\circ} \mathrm{C}$ for 7 days. All colonies seen was counted and expressed in colony forming unit per gram at the end of the incubation period.

Production of Biosurfactant: The selected samples were inoculated in a $250 \mathrm{ml}$ conical flask having $50 \mathrm{ml}$ of sterile mineral salt medium with $2 \mathrm{ml}$ petrol added as carbon source. The broths were amended with Nystatin to prevent contamination by fungi. A reciprocal shaker was used to incubate the culture broth at $120 \mathrm{rpm}$ for $5-7$ days at $30^{\circ} \mathrm{C}$ (Mulligan, 2005).

Extraction of Biosurfactants: A 50ml R2B broth was used to culture the inoculums to which $1 \mathrm{ml}$ of petrol was added and was incubated at $25^{\circ} \mathrm{C}$ for 7 days with shaking conditions. The cultures were centrifuged at $5000 \mathrm{rpm}, 4^{\circ} \mathrm{C}$ for 30 minutes after incubation to remove the bacteria cells. $1 \mathrm{M} \mathrm{H}_{2} \mathrm{SO}_{4}$ was added to the supernatant to adjust the $\mathrm{pH}$ at 2 with equal volumes of chloroform methanol added in the ratio of 2:1. These mixtures were properly mixed and were left over night for evaporation. The presence of biosurfactant is indicated by a white colored precipitate at the interface of the liquids.

Screening of the Isolates for Biosurfactant Production: Pure cultures of the isolated colonies was obtained and tested for their biosurfactant production by the following methods.

Blood Haemolysis Test: Each Isolated pure culture was streaked on Blood Agar Plate and was incubated for 49 Hours at $37^{\circ} \mathrm{C}$. The presence of clear zone around the colonies was observed (Anandaraj and Thivakaran, 2010).

Foaming Activity: Each pure isolates was grown separately in a $100 \mathrm{ml}$ conical flask, each containing $50 \mu \mathrm{l}$ of nutrient broth medium. After incubation at $31^{\circ} \mathrm{C}$ for 48 hours, it was placed on a shaker for 24 hours and a forming activity if seen is an indication of a positive result (Banant, 1995).

Oil Spreading Techniques (Oil Displacement Activity): To $40 \mathrm{ml}$ distilled water in a Petri dish, $10 \mu 1$ of crude oil was added to the surface to form a thin oil layer. Then $10 \mu 1$ of culture or culture supernatant was gently placed on the centre of the oil layer. The displacement and formation of a clear zone as an indication of a positive result and the diameter of the clear zone was measured after 30 seconds. The clear 
zone is measured in biosurfactant unit which is the amount of surfactant forming $1 \mathrm{~cm}^{3}$ of oil displaced area (Banant, 1995).

Emulsification Assay: According to Cooper and Goldenberg, 1987. $2 \mathrm{ml}$ of petrol was collected into a test tube containing $2 \mathrm{ml}$ of the culture supernatant after centrifugation and was vortexed at a very high speed for 5 minute to make sure of homogenous mixture of both liquid. The activity of emulsification was observed after 12 minutes and was calculated by,

$$
\text { EI }(\mathrm{mm})=\frac{\text { Tota Height og EL }}{\text { Total Height of LL }}
$$

Where $\mathrm{EI}=$ Emulsification index $(\mathrm{mm}) ; \mathrm{EL}=$ Emulsified Layer; LL = Liquid Layer

The Effect of Biosurfactant Producing Microorganism on Metal Removal: The isolates was grown in nutrient broth at a neutral $\mathrm{pH}$ in the presence of $100 \mathrm{ppm}$ of lead and are incubated for 5 five days $\left(37^{\circ} \mathrm{C}, 120 \mathrm{rpm}\right)$ to allow the interaction of the organisms with the metal ions. The samples were withdrawn at 24 hours interval and the concentration of the metal ions left in solution was examined by AAS. Uninoculated flask containing the metal was used as control (Patil et al., 2012).

Growth Kinetics of Isolated Strains: The selected isolates were inoculated in $50 \mathrm{ml}$ mineral salt medium that was adjusted to a $\mathrm{pH}$ of 6,7 and 8 for bacteria isolates using sodium hydroxide and $\mathrm{H}_{2} \mathrm{SO}_{4}$. This was kept in a shaker at $25^{\circ} \mathrm{C}$ for 144 hours at in absorbance $600 \mathrm{~nm}$, reading was taken at regular interval of 12 hours (Dahalan et al., 2014).

\section{RESULTS AND DISCUSSION}

The physicochemical result given in (Table 1) shows that the soil samples are acidic with $\mathrm{pH}$ ranging from 4.82 to 5.62. Organic carbon and THC of crude oil contaminated soils ranged from 5.44 to 5.87 and 2720 to $3110 \mathrm{mg} / \mathrm{kg}$ respectively. Iron, zinc and copper content in contaminated soil ranges from 0.10 to 0.42 $\mathrm{mg} / \mathrm{kg}, 1.42$ to $2.17 \mathrm{mg} / \mathrm{kg}$ and 0.05 to $0.45 \mathrm{mg} / \mathrm{kg}$ for copper. Lead ranged 0.54 to 1.38 in contaminated soil. Table 2 shows the mean total heterotrophic and hydrocarbon utilizing count in $\mathrm{cfu} / \mathrm{g}$ of the soil samples in which Batan community had the highest mean heterotrophic and hydrocarbon utilizing bacteria count of $1.6 \pm 0.7 \times 10^{6}$ and $1.2 \pm 0.4 \times 10^{6}$ respectively while Odidi community having the least of $1.4 \pm 0.4 \times 10^{6}$ and $1.0 \pm 0.2 \times 10^{6}$ respectively. Figure 1 shows the prevalence of bacteria isolates. Bacillus subtilis and Pseudomonas aeruginosa had the highest prevalence of $100 \%$. Table 3 shows the result for blood hemolysis test and foaming activity. Corynebacterium, Bacillus subtilis, Pseudomonas aeruginosa and Micrococcus varians showed positive result by the formation of a clear zone around the colonies. Corynebacterium spp., Bacillus substilis, Pseudomonas aeruginosa and Micrococcus varians also showed good foaming activity. Table 4 shows the result of oil spreading technique with Corynebacterium spp., Bacillus substilis, Pseudomonas aeruginosa and Micrococcus varians showing positive results with Pseudomonas aeruginosa having the highest diameter width of 5.2 $\mathrm{cm}$ and Corynebacterium spp. having the least width of $2.5 \mathrm{~cm}$.

\begin{tabular}{|c|c|c|c|c|c|}
\hline $\begin{array}{l}\text { Soil } \\
\text { Parameters }\end{array}$ & Unit & Batan & Odidi & Kantu & $\begin{array}{l}\text { Uncontaminated } \\
\text { Soil }\end{array}$ \\
\hline $\mathrm{pH}$ & & 5.62 & 5.42 & 4.82 & 6.90 \\
\hline $\mathrm{K}^{+}$ & $\mathrm{mg} / \mathrm{kg}$ & 0.80 & 0.20 & 0.71 & 10.04 \\
\hline $\mathrm{Na}^{+}$ & $\mathrm{mg} / \mathrm{kg}$ & 0.78 & 0.07 & 0.81 & 10.03 \\
\hline $\mathrm{Mg}^{2+}$ & $\mathrm{mg} / \mathrm{kg}$ & 0.84 & 0.54 & 0.42 & 10.09 \\
\hline $\mathrm{Ca}^{+}$ & $\mathrm{mg} / \mathrm{kg}$ & 4.86 & 3.65 & 4.89 & 12.05 \\
\hline $\mathrm{SO}_{4}{ }^{2-}$ & $\mathrm{mg} / \mathrm{kg}$ & 5.88 & 4.32 & 2.50 & 11.20 \\
\hline $\mathrm{NO}_{3}^{-}$ & $\mathrm{mg} / \mathrm{kg}$ & 4.05 & 5.64 & 3.81 & 20.40 \\
\hline $\mathrm{Fe}^{2+}$ & $\mathrm{mg} / \mathrm{kg}$ & 0.42 & 0.38 & 0.10 & 0.01 \\
\hline $\mathrm{Zn}^{2+}$ & $\mathrm{mg} / \mathrm{kg}$ & 2.17 & 1.58 & 1.42 & 0.34 \\
\hline $\mathrm{Cu}^{2+}$ & $\mathrm{mg} / \mathrm{kg}$ & 0.09 & 0.05 & 0.45 & 0.01 \\
\hline $\mathrm{Pb}^{2+}$ & $\mathrm{mg} / \mathrm{kg}$ & 1.42 & 0.54 & 1.38 & 0.09 \\
\hline Org Carbon & $\%$ & 6.87 & 6.40 & 5.44 & 2.23 \\
\hline THC & $\mathrm{Mg} / \mathrm{kg}$ & 3110.00 & 2720.00 & 2984.00 & 105.12 \\
\hline
\end{tabular}

Table 5 shows the emulsification index of the bacteria isolates with Pseudomonas aeruginosa showing the highest emulsification activity of $51 \mathrm{~mm}$ while Corynebacterium spp. had the least emulsification activity of $26 \mathrm{~mm}$. Corynebacterium spp., Bacillus substilis, Pseudomonas aeruginosa and Micrococcus varians had metal removal capacity of $16.26 \%$, $29.44 \%, 27.77 \%$ and $19.78 \%$ respectively. Figure 3 shows the growth kinetics of Corynebacterium spp., having maximum growth at $\mathrm{pH} 8$ after 48 hours. The maximum growth was around $0.11 \mathrm{~nm}$. Figure 4 shows the growth kinetics of Bacillus subtilis, having 
the optimum growth at pH 6 and 7 after 36 hours. Figure 5 shows the growth kinetics of Pseudomonas aeruginosa having optimum growth at $\mathrm{pH} 8$ after 36 hours. Figure 6 shows growth kinetics of Micrococcus varians having optimum growth at $\mathrm{pH} 8$ after 60 hours.

This analysis shows that the $\mathrm{pH}$ of the contaminated soil samples were more acidic than the uncontaminated soil sample (Chukwuma et al. (2010). In all the soil samples, the concentration of potassium, sodium, magnesium, calcium, sulphate and nitrate was lower than those of the uncontaminated soil. However, the concentration of iron, zinc, copper and lead were higher in the contaminated soil sample than that of the uncontaminated soil which agrees with (Lloyd and Caskette, 2001) who reported a higher concentration of the element in top soil parts and roots of yellow lupine when the soil was polluted with diesel. Thus this high concentration of metal on crude oil contaminated soil may be as a result of the constant and continuous spillage of petroleum product on the soil which accumulated overtime.

\begin{tabular}{|c|c|c|}
\hline \multirow{2}{*}{ Locations } & Total Heterotrophic & Hydrocarbon \\
\hline & $\begin{array}{l}\text { Bacteria Count } \\
(\mathrm{Cfu} / \mathrm{G})\end{array}$ & $\begin{array}{l}\text { Utilizing Bacteria } \\
\text { Count }(\mathrm{Cfu} / \mathrm{G})\end{array}$ \\
\hline Batan community & $1.6 \pm 0.7 \times 10^{6}$ & $1.2 \pm 0.4 \times 10^{6}$ \\
\hline Odidi community & $1.4 \pm 0.4 \times 10^{6}$ & $1.0 \pm 0.2 \times 10^{6}$ \\
\hline Kantu community & $1.5 \pm 0.6 \times 10^{6}$ & $1.1 \pm 0.3 \times 10^{6}$ \\
\hline
\end{tabular}

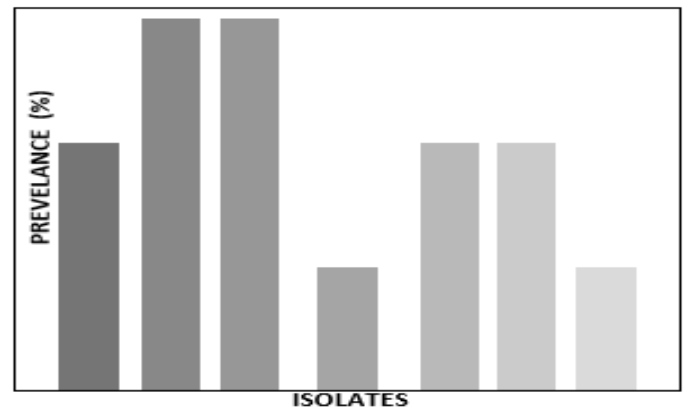

Fig 1: Prevalence of bacteria isolate in crude oil contaminated soils.

Table 3: Blood haemolysis test for bacteria strain

\begin{tabular}{lll}
\hline Bacteria Strain & $\begin{array}{c}\text { Blood } \\
\text { Haemolysis }\end{array}$ & $\begin{array}{c}\text { Foaming } \\
\text { Activity }\end{array}$ \\
\hline Corynebacterium spp. & Positive & Positive \\
Bacillus subtilis & Positive & Positive \\
Pseudomonas aeruginosa & Positive & Positive \\
Micrococcus varians & Positive & Positive \\
Streptococcus spp. & Negative & Negative \\
Enterobacter spp. & Negative & Negative \\
Klebseillia spp. & Negative & Negative \\
\hline
\end{tabular}

Table 4: Oil Spreading Techniques of Bacteria isolates

\begin{tabular}{lll}
\hline Bacteria Isolates & Diameter $(\mathrm{Cm})$ & Interpretation \\
\hline $\begin{array}{l}\text { Corynebacterium } \\
\text { spp. }\end{array}$ & 2.5 & Positive \\
Bacillus spp. & 5.0 & \\
Pseudomonas spp. & 5.2 & Positive \\
Micrococcus & 5.0 & Positive \\
Streptococcus spp. & Nil & Positive \\
Klebsiella spp. & Nil & Negative \\
Enterobacter spp. & Nil & Negative \\
\hline
\end{tabular}

Table 5: The emulsification index of bacteria strain:

\begin{tabular}{|c|c|c|c|}
\hline Bacteria Isolates & $\begin{array}{l}\text { Height Of } \\
\text { Emulsion } \\
\text { Layer }(\mathrm{Mm})\end{array}$ & $\begin{array}{lr}\text { Total } & \text { Height } \\
\text { Of } & \text { Liquid } \\
\text { Column }(\mathrm{Mm})\end{array}$ & $\begin{array}{l}\text { Percentage } \\
\text { emulsification } \\
\text { index }\end{array}$ \\
\hline Corynebacterium spp. & 8 & 32 & 25 \\
\hline Bacillus subtilis & 15 & 30 & 50 \\
\hline Pseudomonas aeruginosa & 16 & 31 & 51 \\
\hline Micrococcus varians & 12 & 30 & 40 \\
\hline Streptococcus spp. & Nil & Nil & Nil \\
\hline Klebsiella spp. & Nil & Nil & Nil \\
\hline Enterobacter spp. & Nil & Nil & Nil \\
\hline
\end{tabular}

The bacteriological analysis revealed a relatively high count in different soil samples. This high microbial load may be attributed to the existence of the normal flora of the soil and the ability of the isolated microorganisms to use petroleum product as sole carbon and energy source (Oluwafemi et al., 2008). The isolates identified from the crude oil contaminated soil were Corynebacterium spp., Bacillus substilis, Pseudomonas aeruginosa, Micrococcus varians, Streptococcus spp., Klebsiella spp. and Enterobacter spp. (Adam et al., 2014). These bacteria isolates have also been isolated from oil contaminated soil from Niger Delta aquatic system as hydrocarbon utilizing isolates as reported by (Ekaise and Nkwelle, 2011).
The isolates Corynebacterium spp., Bacillus substilis, Pseudomonas aeruginosa and Micrococcus varians, showed positive result in all the five screening method used. Thus, it was observed that these isolates can produce biosurfactant. This is in accordance with the report of (Tabatabace et al., 2005). Observation from haemolysis activity with the selected isolates showed positive result. This is in agreement with Nasr et al. (2009) who screen biosurfactant produced by Bacillus substilis and Pseudomonas aeruginosa using blood haemolysis test. Oil spreading method showed that the activity of the biosurfactant clearance zone on the soil surface correlate to the activity of the surfactant. 


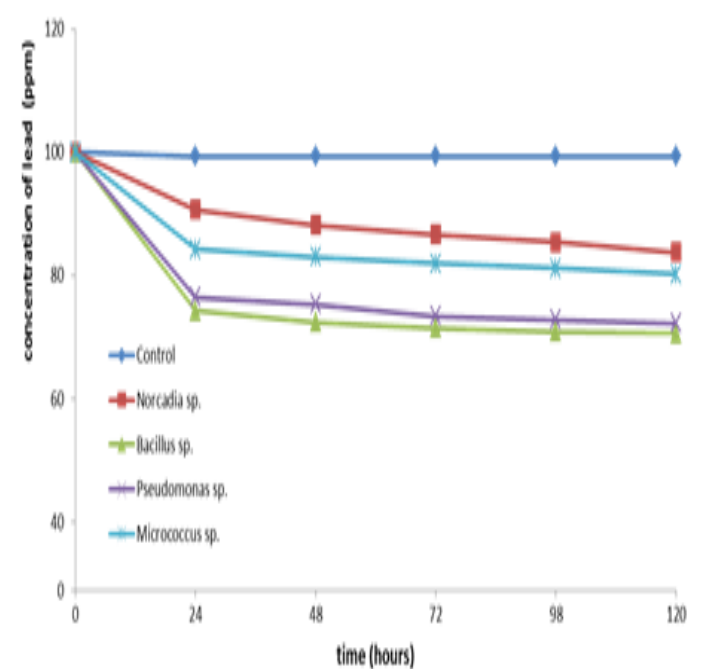

Fig 2: Heavy metal removal analysis of bacteria isolates by AAS (600nm)

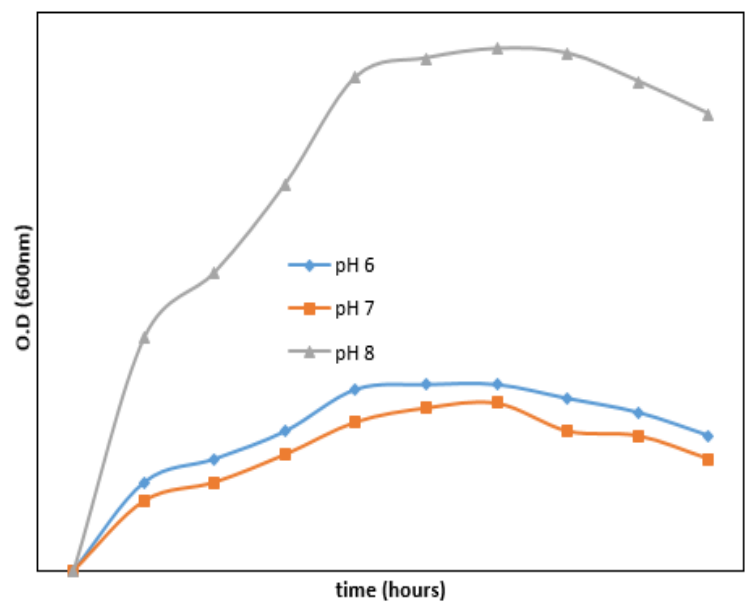

Fig 3: Growth kinetics of Corynebacterium spp., at pH 6, pH 7 and $\mathrm{pH} 8$

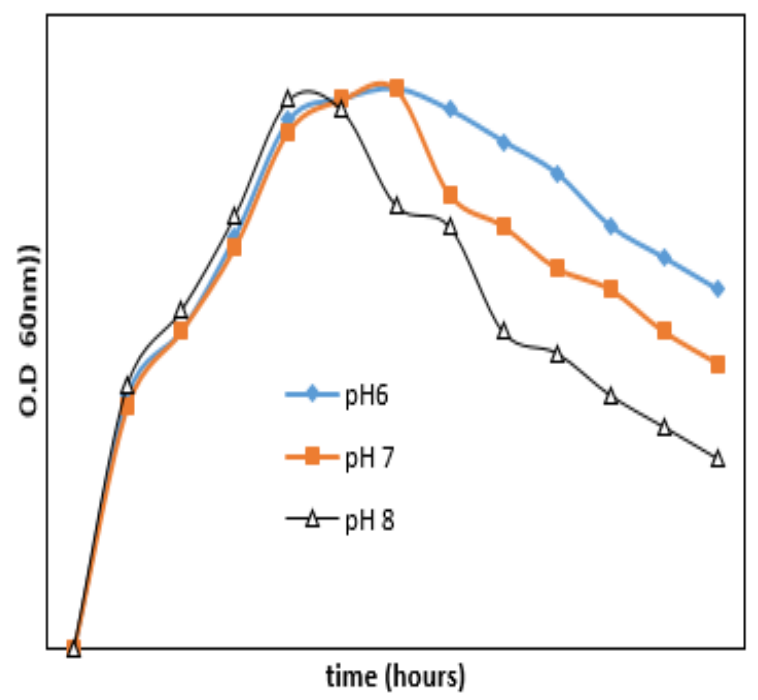

Fig 4: Growth kinetics of Bacillus subtilis at $\mathrm{pH} 6,7$, and 8
Previous report by Nasr et al. (2009) also shows biosurfactant activity by Bacillus spp. (19 mm), Micrococcus spp. (21 mm) Pseudomonas spp. (15 $\mathrm{mm}$ ) which is similar with this study. Emulsification activity shows that Pseudomonas spp. was the best organism for biosurfactant production since the emulsification index was observed to be highest with Pseudomonas spp. This could be as a result of readily used nutrient in the broth medium. This finding is similar with those of Oluwafemi et al. (2008) who showed similar result with Pseudomonas spp. as good emulsifier and with emulsification index of $72 \%$.

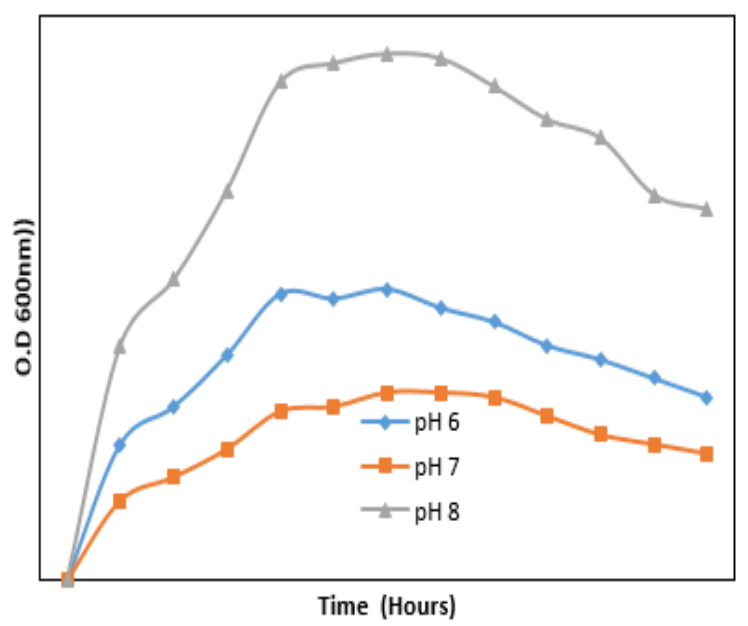

Figure 5: Growth kinetics of Pseudomonas aeruginosa at $\mathrm{pH}$ 6,7 and 8

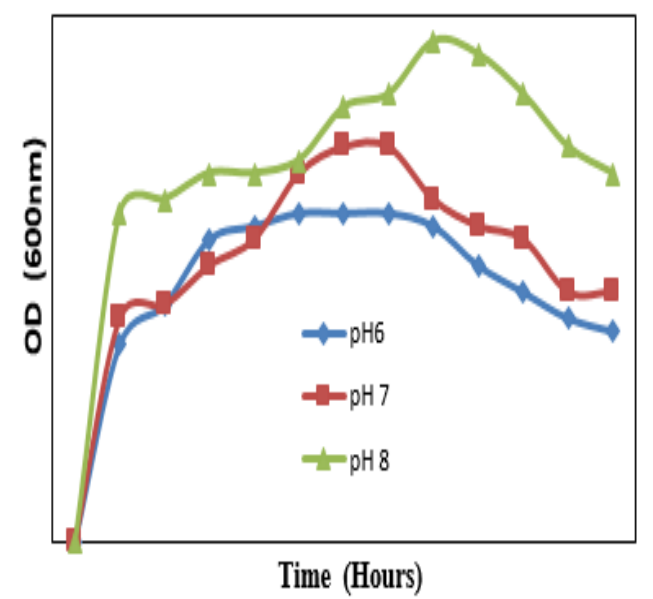

Fig 6: Growth kinetic for Micrococcus varians $\mathrm{pH}$ 6, 7, and 8

Among the various heavy metals contaminant, lead is known to be the leading toxicant worldwide and having various toxic effect on animal and human health as well as the environment. Thus there is need to remove these metals from the soil using microbes. Bacteria, fungi, yeast and algae can remove heavy metals and radio nucleotide from aqueous solution and in substantial amount as stated by (Yun and 
Vijayaraghavan, 2008). They do not degrade heavy metals directly but can vange the valence state of metals into immobile or less toxic forms through biosurption of lead by functional group on the cell surface by complex formation and interaction between the acidic sites in the cell wall. This could be achieved via exclusion by intra and extracellular sequentiation, forming a permeable barrier, chelation and active transport enzymatic detoxification. This study reveals that the bacteria isolates Bacillus subtilis, Pseudomonas aeruginosa, Corynebacterium spp. and Micrococcus varians could remove about $16-30 \%$ metal from the media. This result is in agreement with Mulligan, (2005). This result also reveals that the isolates were tolerant to metal concentration of $100 \mathrm{ppm}$. Thus resistance may be due to the ability of biosurfactant to complex with metal ions solution effectively (Atuanya and Osaghe, 2000).

Conclusion: This study has shown that Corynebacterium spp., Bacillus substilis, Pseudomonas aeruginosa and Micrococcus varians are capable of producing biosurfactant through systematic screening. These organisms are resistance to metals and are able to remove metals from crude oil contaminated soil. Based on their biodegradability and low toxicity, biosurfactant may have a promising future for use in cleaning up crude oil and heavy metal polluted soil.

\section{REFERENCES}

Adams, G. O; Tawari-fufeyin, P; Igelenyah, E. (2014). Laboratory Scale Bioremediation of soils from Automobile Mechanic Workshops using Cow Dung. J. Appl. Environ. Microbe. 2: 128-134.

Adelekan, B.A; Abegunde, K.D. (2011).Heavy metals contamination of soil and groundwater at automobile mechanic village in Ibadan, Nigeria. Inter. J. Phy. Sci.6 (5):1045 - 1058.

Akpoveta, O. V; Egharevba, F; Medjor, O. W; Osaro, M; Enyemike, E. J. (2011). Microbial degradation and its kinetics on crude oil polluted soil. Res. J. Chem. Sci. 1: $8-14$.

Amund, O. O; Olusola, O. O. (1987). Extracellular amylase production by cassava - fermenting bacteria. J. Indust. Microb. 2: 123 - 127.

Anandaraj, B; Thivakara, P. (2010). Isolation and production of biosurfactant producing organism from oil spilled soil. J. Biosci. Tech. 1(3): 120-126.
Atuanya, E. I; Oseghe, E. O. (2000). Lead contamination and Microbial Lead tolerance in soil at Major road junctions in Benin City. J. Appl. Sci. Environ. Manage. 10(2): 99-104.

Banat, I. M. (1995). Biosurfactant production and possible uses in microbial enhanced oil recovery and oil pollution remediation: A review bioresource technology 51: $1-2$.

Chukwuma, M. C; Oko, M. A.; Onweremadu, E. U. (2010). Zinc availability in relation to selected soil properties in a crude oil polluted eutrictropofluvent. International Journal of Science and Technology, 7: 261 - 270.

Dahalan, S. F. (2014). Growth kinetic of a diesel degrading bacteria strain from petroleum contaminated soil. Journal of Environmental Biology. 3(2): 399 - 406.

Guerra-Santos, L. H; Kappeli, O; Fletcher, A. (1984).Pseudomonas aeruginosa Biosurfactant production in continuous culture with glucose as carbon source. Appl. Microbiology Biotechnology. 48: 301-305

Guerra-Santos, L. H; Kappeli, O; Fletcher, A. (1986). Dependence of Pseudomonas aeruginosa continuous culture Biosurfactant production on Nutritional and Environmental factors. Appl. Microbiol. Biotech. 24: 443-448.

Hauser, G; Karnovsky, M.L. (1954).Studies on the production of glycolipide by Pseudomonas aeruginosa. J. Bacteriology. 68: 645-654

Karanth, N. G. K; Deo, P. G; Veenanadig, N. K. (1999). Microbial production of biosurfactants and their importance. Cur. Sci.. 77: 116-123.

Karthik, L; Gaurav, Kumar; BhaskaraRao, K. V. (2010). Diversity of marine actimycetes from nicober marine sediment and its antifungal activity. Inter. J. Pharm. Pharm. Sci. 2(1): 199 203

Kiran, G.S; Hema, T.A., Gandhimalhi, R., Selvin, J. and Thomas, T.A. (2009). Optimization and production of a biosurfactant from the spongeassociated marine fungus Aspergillus bustus MSF3.Colloids Surf B Bioinlerfaces. 73: 250-256.

Lloyd, C. A; Caskette, T. O. (2001). Diesel engines environmental impact and control. Air and Water Manage. Assoc. 51: 805 - 847. 
Morikawa, M.; Daido, H; Takao, T; Murata, S; Shimonishi, V; Imanaka, T. (1993). A new lipopeptide biosurfactant produced by Arthobacter spp. Strain Mis 38. J. Bacterialogy. 175: $6459-6466$.

Mulligan, C. N. (2005). Environmental applications for biosurfactants. Environ. Pollute. 133: 183198.

Nasr, S.I; Soud, M.R.I; Mehrnia, M.E.I; Sorafzadeh, M.H. (2009). Characterization of novel biosurfactant producing strain of Bacillus spp. isolated from petroleum contaminated soil. Environ. J. Microbiol. 1(2): 154 - 161.

Oluwafemi, S. O; Matthew, O. I; Sunday, A. A; Olukayode, O. A; Ganiyu, O. O. (2008). Microbial population changes in tropical agricultural soil experimentally contaminated with crude petroleum. Afr. J. Biotech. 7(24): 4512 -4520 .
Onyeonwu, R. O. (2000). Manual for waste/ waste water, soil/sediment, plant and fish analysis. Environmental Research Laboratory Manual, MacGill Publisher, Benin - city. 81p.

Patil, S. N; Aglave, B. A; Pathkar, A. V; Gaikwad, V. B. (2012). Stenotrophononaskoreansis a novel biosurfactant producer for abatement of heavy metals from the environment. Afr. J. Microbio. Res. 6(24): 5173 - 5178.

Tabatabaee. Mzaheri, A. A; Nooki, A; Sajadian, Y. A. (2005). Isolation of biosurfactaral producing bacteria from oil reservoirs. Iran J. Environ. Health Sci. 2: 6-12.

Yun, Y; Vijayaraghavan, S. (2008). Bacteria biosorbent and biosorption. Biotech. Adv. 26: 262 $-291$. 